\title{
EFFECT OF 1-MCP TREATMENT ON STORAGE POTENTIAL OF TOMATO FRUIT
}

\author{
Anna WRZODAK ${ }^{1 *}$, Marek GAJEWSKI ${ }^{2}$ \\ ${ }^{1}$ Research Institute of Horticulture, Konstytucji 3 Maja 1/3, 96-100 Skierniewice, Poland \\ ${ }^{2}$ Warsaw University of Life Sciences - SGGW, Department of Vegetable and Medicinal Plants, \\ Nowoursynowska 159, 02-776 Warszawa, Poland
}

Received: September 2015; Accepted: November 2015

\begin{abstract}
Tomato fruit $\mathrm{cv}$. 'Faustine' $\mathrm{F}_{1}$ were harvested at mature green and full-red stages and treated with 1 or $2 \mu 1 \cdot 1^{-1}$ of 1-methylcyclopropene (1-MCP) at $20{ }^{\circ} \mathrm{C}$ and $85-90 \% \mathrm{RH}$, for 21 hours to investigate the ability to delay ripening. Treated and control fruit were stored at 12.5 and $20^{\circ} \mathrm{C}$ and $85-90 \% \mathrm{RH}$. Ethylene production, rate of respiration, weight loss, market value and storage life were determined after 4-week storage. Exposure of tomato fruit to 1-MCP reduced ethylene production and respiration rate of the fruit harvested at mature-green and full-red stages of maturity. Storage life and market value of tomato fruit depended on the treatment with 1-MCP, stage of maturity and storage temperature. Untreated fruits were characterized by the shortest storage life in comparison with the fruit treated with 1-MCP. The lowest market value was observed for tomato fruit harvested as a mature green, untreated with 1-MCP and stored at $20{ }^{\circ} \mathrm{C}$. Treatment of tomato fruit with 1-MCP resulted in the reduction of natural weight loss during storage. These results suggest that 1-MCP treatment can be used in a commercial storage and trading system for tomatoes due to its ability to delay fruit ripening.
\end{abstract}

Key words: tomato fruit, 1-methylcyklopropene, ethylene, storage potential

\section{INTRODUCTION}

Quality of tomato fruit during storage depends on many factors such as cultivation methods, postharvest handling, cultivar, stage of maturity at harvest. In Poland, in commercial field production of tomatoes for consumption during summer and autumn, interest in growing tomato plants at stakes has been increasing (Suszyna 2006).

Storage temperature is the most important factor for the post-harvest life of the fruit (Mostofi \& Toivonen 2006). The most appropriate temperature for storage of tomato fruit harvested at the maturegreen stage is $12.5-13{ }^{\circ} \mathrm{C}$ (Adamicki 1991; Castro et al. 2005; Gajewski 2001). Red tomatoes can be stored at temperature of $6-8{ }^{\circ} \mathrm{C}$, but considerably shorter than the mature-green ones.
1-Methylcyclopropene (1-MCP) radically inhibits ripening of tomato fruit. The increase in ethylene production and internal ethylene concentration associated with the climacteric stage of ripening are delayed by 1-MCP treatment (Hoeberichts et al. 2002; Krammes et al. 2003; Opiyo \& Ying 2005). Other ripening processes that are inhibited include respiration (Colleli et al. 2003; Wills \& $\mathrm{Ku}$ 2002), color change and softening (Mir et al. 2004; Mostofi et al. 2003; Opiyo \& Ying 2005). Generally, 1-MCP treatment influences physicochemical changes of tomato fruit, as well as a reduction in decay, weight loss and extends storage life of the fruit (Blankenship \& Dole 2003).

The objective of the present study was to examine the effects of 1-MCP treatment on ethylene production, rate of respiration and storage life of tomato fruit stored at two temperatures $-12.5^{\circ} \mathrm{C}$ and $20^{\circ} \mathrm{C}$. 


\section{MATERIALS AND METHODS}

In the experiment conducted in the two growing seasons (2008 and 2009), tomato fruit (Lycopersicon esculentum Mill.) cv. Faustine $\mathrm{F}_{1}$ (Syngenta Seeds, Ltd., Holland; $\mathrm{TmVF}_{2} \mathrm{~N}$ ) were used. The cultivar has a commercial value, recommended for growing at stakes in the open field production. Standard cultivation practices, such a soil preparing, planting and plant protection, were applied for the crop in vegetation periods.

The fruit for the experiment were harvested at mature green (MG) and full-red (R) stages (1st and 6th maturity stages, according to USDA classification). Fruit of the same size and shape without defects or diseases, without a calyx, were selected for the experiment. Prior to storage, the fruit were washed in water, then dipped in an aqueous solution of sodium hypochlorite $(0.03 \%)$ for disinfection and subsequently dried before being placed in storage boxes. Each treatment was made up in four replications, consisting of 20 fruit in each. Three-way analysis of variance in a completely randomized design was carried out.

Gaseous 1-MCP was prepared from SmartFresh $^{\mathrm{TM}}$ (AgroFresh Inc.) commercial powder $\left(0.14 \%\right.$ of active ingredient). SmartFresh ${ }^{\mathrm{TM}}$ was applied on the day of harvest for each stage of maturity, in special air-tight steel containers (capacity of $1 \mathrm{~m}^{3}$ ) applying 1.0 and $2.0 \mu \mathrm{l} \cdot \mathrm{l}^{-1}$ of 1-MCP for $21 \mathrm{~h}$, at the temperature of $20^{\circ} \mathrm{C}$ and $85-90 \% \mathrm{RH}$. Control fruit were kept under similar conditions, but without 1-MCP treatment. After treatment, the fruit were stored for 4 weeks at $12.5^{\circ} \mathrm{C}$ or $20^{\circ} \mathrm{C}$, and 85 $90 \%$ RH in air in the dark.

After the storage, the following quality attributes were determined: weight loss (in \%); fruit market value in 1-9 point grading scale, according to Adamicki (1991), Getinet et al.(2008) and Telefera et al. (2007); where $9=$ the highest quality, $7=$ good, $5=$ satisfactory, $3=$ poor (i.e. no market and consumption value), $1=$ very bad. The observations concerning the market value of the fruit were carried out at three-day intervals, while removing fruit with diseases symptoms. Storage potential was determined as the number of days from the time of reaching full maturity until obtaining the market value score of 5 (limit of marketability) and the market value 3 (poor).
Respiration rate was determined on the basis of $\mathrm{CO}_{2}$ production. Tomato fruit (samples of $1 \mathrm{~kg}$ ) were put to glass jars (volume of $5 \mathrm{~L}$ each) with lids, equipped with valves enabling taking small air samples from the jars to analyze. After 3 hours of keeping the fruit at the temperature of $20{ }^{\circ} \mathrm{C}$, the $\mathrm{CO}_{2}$ concentration (in v.v. \%) in the jars was measured using gas analyzer COMBO 280 (David Bishop Instr., UK). The measurements were done in a laboratory, at room temperature $\left(20^{\circ} \mathrm{C}\right)$, in three replicates. The data obtained were used to calculate $\mathrm{CO}_{2}$ production, which was expressed in $\mathrm{ml} \mathrm{CO}_{2} \cdot \mathrm{kg}^{-1} \cdot \mathrm{h}^{-1}$.

To determine ethylene production, the same method as above was applied. Ethylene concentration in the jars (in ppm) was measured with ICA 56 ethylene analyzer (ICA Instruments, USA) and expressed as $\mu 1 \mathrm{C}_{2} \mathrm{H}_{4} \cdot \mathrm{kg}^{-1} \cdot \mathrm{h}^{-1}$.

For the analysis of variance, Statistica ver. 10 software with three-factor ANOVA was applied (factor A - stage of maturity, B - treatment with 1$\mathrm{MCP}, \mathrm{C}$ - storage temperature). Mean values were compared using the Tukey's HSD test at the significance level of $p=0.05$.

\section{RESULTS AND DISCUSSION}

If we compare the respiration rate for the tomato fruit before and after storage, it can be seen that the rate decreased markedly for the fruit kept at $20{ }^{\circ} \mathrm{C}$ (Fig. 1). However, for the fruit stored at $12.5^{\circ} \mathrm{C}$ only small changes in respiration rate was observed, in general. This phenomenon could be explained by faster ripening of the fruit kept at the higher temperature, which caused faster entry into the lower point on a climacteric curve. As the confirmation of this statement, we can point out that fruit of a non-climacteric tomato cultivar LSL showed quite different reaction of storage temperature on respiration rate, and the respiration at $20^{\circ} \mathrm{C}$ was higher than at $12{ }^{\circ} \mathrm{C}$ (our own data, unpublished yet). The other reason can be due to thermal shock - as the fruit stored for a long period at $12.5^{\circ} \mathrm{C}$ in storage chamber were transferred for the measurement to the laboratory condition $\left(20^{\circ} \mathrm{C}\right)$. Respiration rate of the fruit during the storage period differed in relation to the treatment. Generally, the control tomatoes produced more $\mathrm{CO}_{2}$ compared to the 1MCP treated samples. As it can be seen in Fig. 1, 
the highest respiration rate was noted before storage for the control fruit of both stages of maturity $\left(12.2\right.$ and $\left.13.6 \mathrm{ml} \mathrm{CO} \cdot \mathrm{kg}^{-1} \cdot \mathrm{h}^{-1}\right)$ and after storage at $12.5^{\circ} \mathrm{C}\left(10.9\right.$ and $\left.10.4 \mathrm{ml} \mathrm{CO}_{2} \cdot \mathrm{kg}^{-1} \cdot \mathrm{h}^{-1}\right)$. The rate of respiration was mainly dependent on 1-MCP treatment. However, stage of maturity and storage temperature also showed a significant influence on the rate of respiration. Pangaribuan \& Irving (2010) showed that tomato slices at the pink maturity stage treated with $1-\mathrm{MCP}$ at $1.0 \mu \mathrm{l} \cdot \mathrm{l}^{-1}$ concentration were characterized by reduced res- piration rate after one day of storage compared with the control fruit. As it was already pointed out above, our results showed that the maturegreen and full-red tomatoes stored at $12.5^{\circ} \mathrm{C}$ were characterized by a higher production of $\mathrm{CO}_{2}$ compared with the fruit stored at $20{ }^{\circ} \mathrm{C}$. The lowest rate of respiration was observed for the untreated tomato fruit after storage at $20{ }^{\circ} \mathrm{C}$, regardless of the stage of maturity $\left(4.9 \mathrm{ml} \mathrm{CO}{ }_{2} \cdot \mathrm{kg}^{-1} \cdot \mathrm{h}^{-1}\right.$ for mature-green and $4.6 \mathrm{ml} \mathrm{CO}{ }_{2} \cdot \mathrm{kg}^{-1} \cdot \mathrm{h}^{-1}$ for fullred fruit).

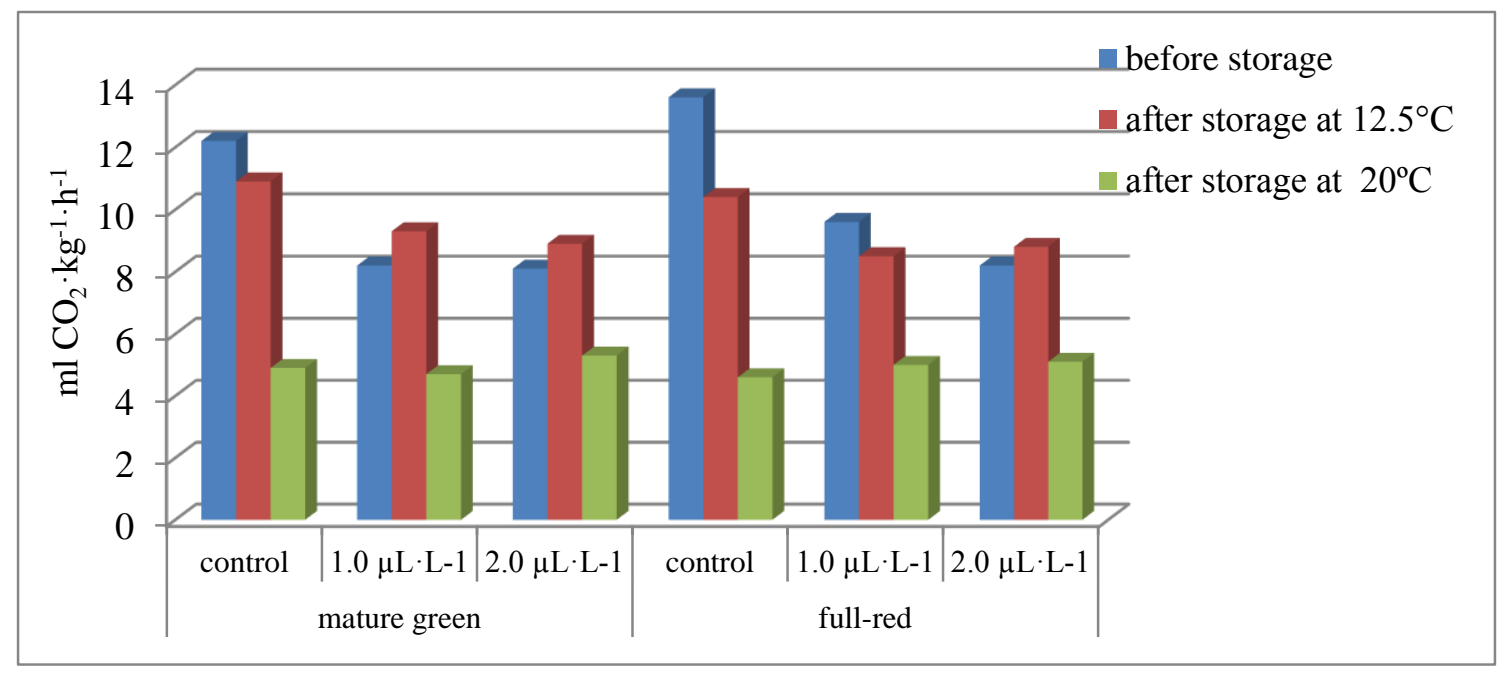

Fig. 1. Effect of treatment with 1-MCP on rate of respiration for tomato fruit cv. Faustine $\mathrm{F}_{1}$ during storage at 12.5 and $20{ }^{\circ} \mathrm{C}$ in $2009\left(\mathrm{ml} \mathrm{CO}_{2} \cdot \mathrm{kg}^{-1} \cdot \mathrm{h}^{-1}\right) . \mathrm{LSD}_{0.05} \mathrm{~A} \times \mathrm{B} \times \mathrm{C}=1.9$

Tomato, as well as other climacteric fruits, is characterized by a rise in ethylene production, reaching the climacteric peak (Leliévre et al. 1997). Low temperature during the storage is not sufficient to inhibit ethylene production and the related ripening processes, so there is consequently a need to have new tools to inhibit and/or to delay ethylene production.

In our experiment, the treatment with 1-MCP resulted in decrease of ethylene production of the tomato fruit harvested at both stages of maturity (Fig. 2). Initial ethylene production of the maturegreen harvested fruit was lower than for the full-red fruit. After 4 weeks of storage of the tomato fruit at both temperatures, ethylene production for the mature-green ones was still lower than for the full-red fruit. The results showed lower production of ethy- lene for the fruit stored at $20{ }^{\circ} \mathrm{C}$ than at $12.5^{\circ} \mathrm{C}$. The reasons of this phenomenon could be the same as for respiration rate relationship, which is explained above. The highest ethylene production at $12.5^{\circ} \mathrm{C}$ was noted for the mature-green tomato fruit untreated with 1-MCP $\left(3.5 \mu 1 \mathrm{C}_{2} \mathrm{H}_{4} \cdot \mathrm{kg}^{-1} \cdot \mathrm{h}^{-1}\right)$, and the lowest for the mature-green fruit treated with 1-MCP after storage at $20^{\circ} \mathrm{C}\left(0.9 \mu \mathrm{C}_{2} \mathrm{H}_{4} \cdot \mathrm{kg}^{-1} \cdot \mathrm{h}^{-1}\right)$. This is in agreement with Wills \& $\mathrm{Ku}$ (2002) report. The authors observed a positive effect of the treatment with $1-\mathrm{MCP}$ for fully ripe tomato fruit cv. 'Clarion' after storage for 5 days at $20^{\circ} \mathrm{C}$ on reduction of ethylene production. However, Hoeberichts et al. (2002) found no effect of 1-MCP treatment on ethylene production for full-red tomato fruit cv. 'Prisca' during storage at $20^{\circ} \mathrm{C}$. 


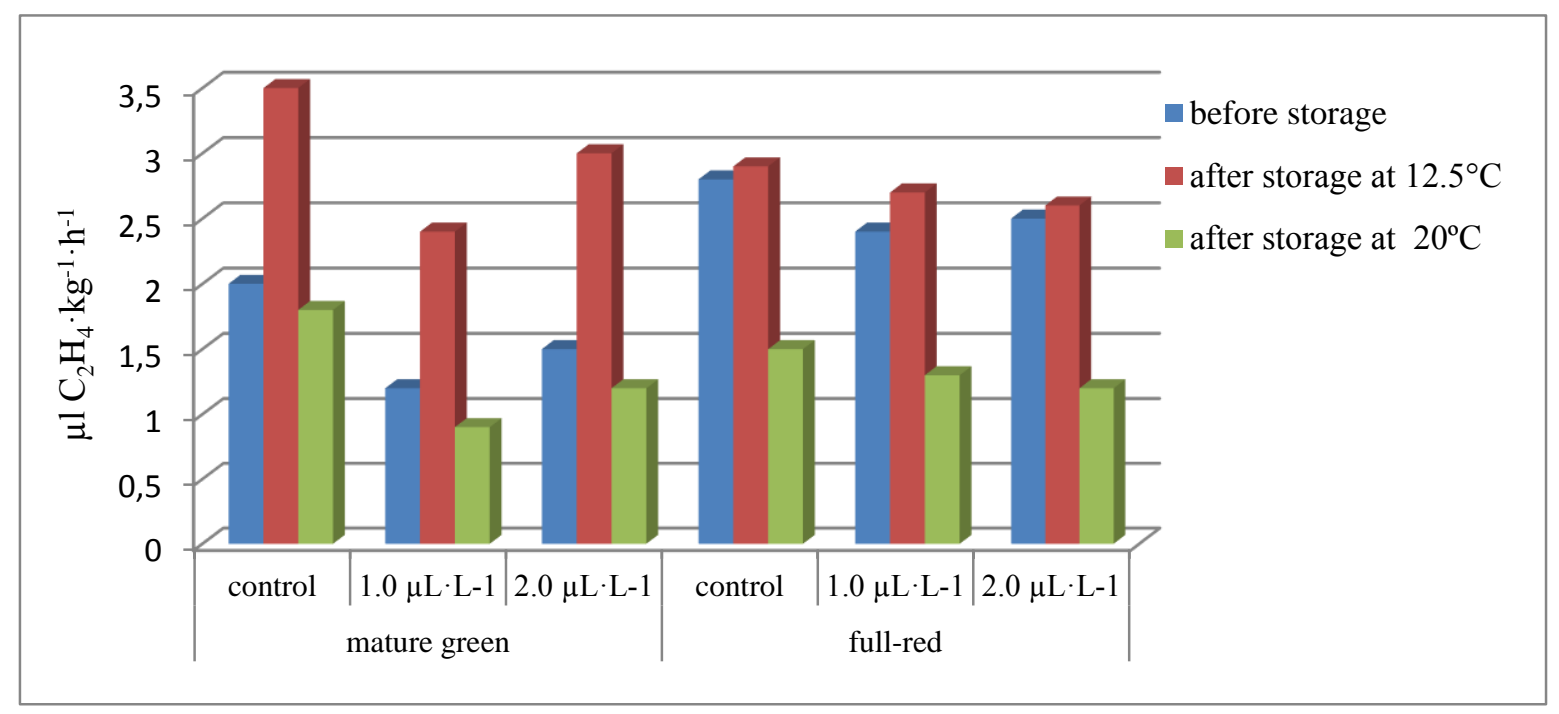

Fig. 2. Effect of treatment with 1-MCP on ethylene production for tomato fruit cv. Faustine $\mathrm{F}_{1}$ during storage at 12.5 and $20{ }^{\circ} \mathrm{C}$ in $2009\left(\mu \mathrm{l} \mathrm{C} \mathrm{H}_{4} \cdot \mathrm{kg}^{-1} \cdot \mathrm{h}^{-1}\right) . \mathrm{LSD}_{0.05} \mathrm{~A} \times \mathrm{B} \times \mathrm{C}=0.4$

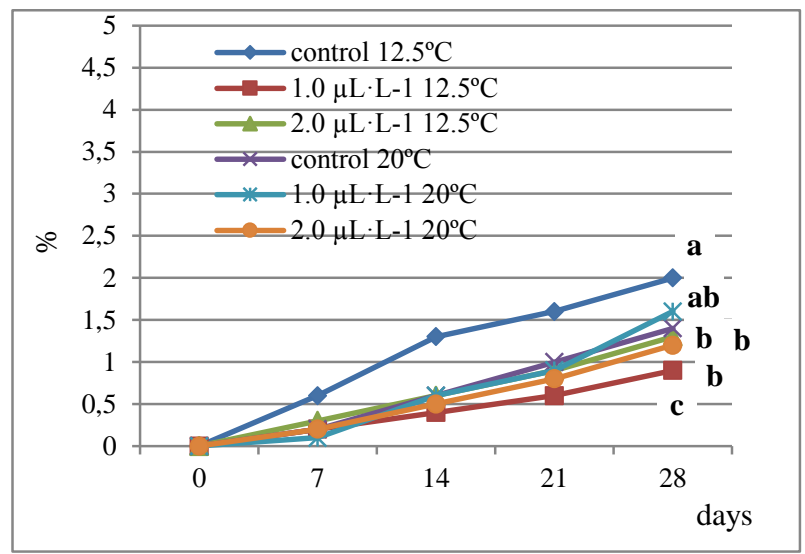

Fig. 3. Effect of 1-MCP on weight loss (\%) for maturegreen tomato fruit during storage in 2008

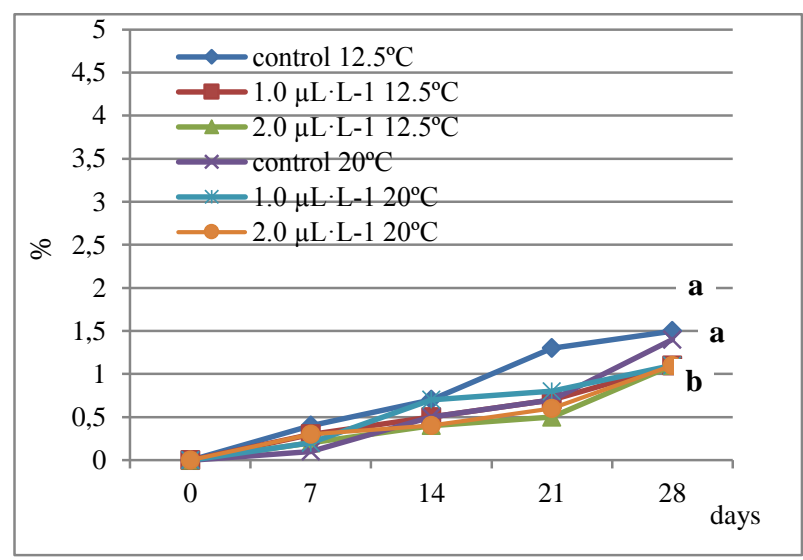

Fig. 5. Effect of 1-MCP treatment on weight loss (\%) for full-red tomato fruits during storage in 2008

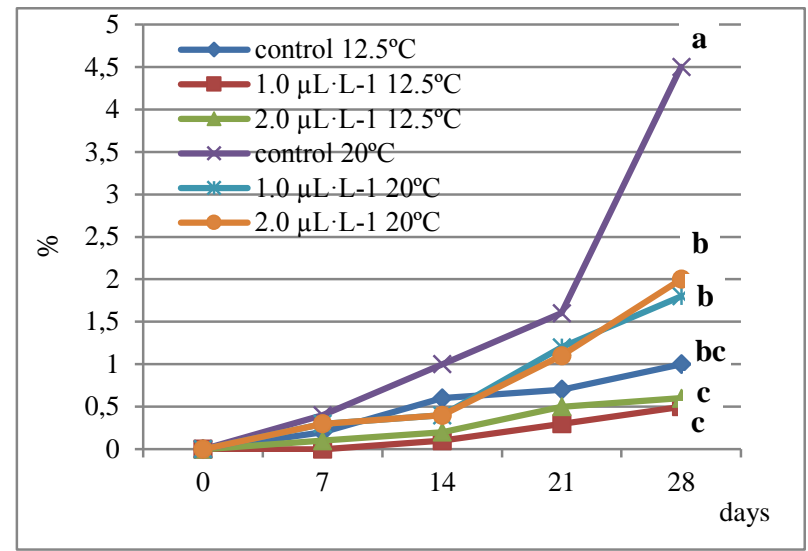

Fig. 4. Effect of 1-MCP on weight loss (\%) for maturegreen tomato fruit during storage in 2009

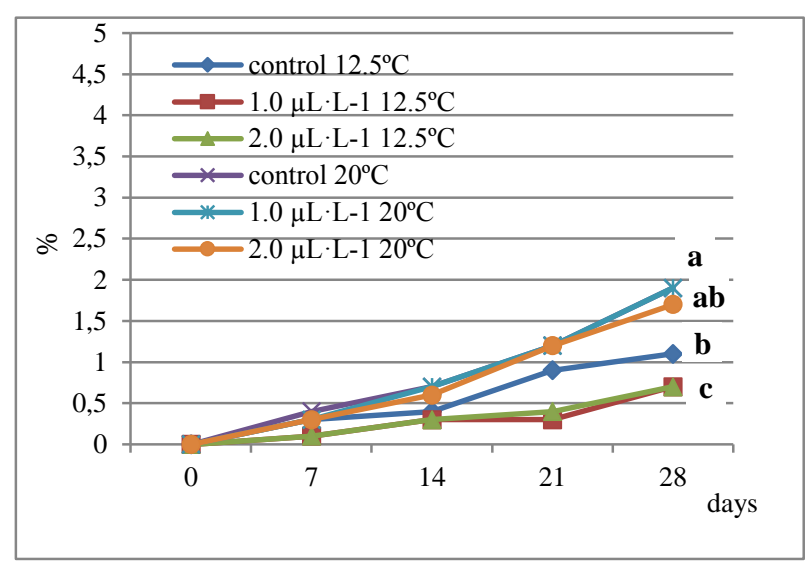

Fig. 6. Effect of 1-MCP treatment on weight loss (\%) for full-red tomato fruit during storage in 2009 
Result of the studies shows the significant differences in the market value and storage potential of tomato fruit depending on the year of cultivation (Table 1). We found better market value for the tomato fruit treated with $1-\mathrm{MCP}$ versus untreated fruit. Treatment of the mature-green and full-red fruit with 1-MCP, as well as storage temperature, significantly affected market value of the fruit. In 2008, the best market quality was obtained for the mature-green fruit treated with 1-MCP, after storage at $12.5{ }^{\circ} \mathrm{C}$ and $20^{\circ} \mathrm{C}(8.9$ and 8.8 points, respectively). Compared to the results from 2009, the best market value was recorded for full-red fruit treated with $1-\mathrm{MCP}$ after storage at $20{ }^{\circ} \mathrm{C}(8.3$ points). The lowest fruit quality in the two years was obtained in 2009 for the control fruit harvested at both stages of maturity, after storage at $20^{\circ} \mathrm{C}$ and $12.5^{\circ} \mathrm{C}$ (6.2 points). Guillen et al. (2007) and Adamicki \& Badełek (2006) obtained similar results. Sun et al. (2003) and Ergun et al. (2006) noted that tomato fruit treated with $1-\mathrm{MCP}$ were firmer at the end of marketable life comparable with the untreated fruit.

Fruit storage potential in 2008, determined as the number of days from the time of reaching full maturity until obtaining the market value score of 5 (limit of marketability), was on average 41 days at $12.5{ }^{\circ} \mathrm{C}$ and 33 days at $20{ }^{\circ} \mathrm{C}$ (mature-green) and for full-red fruit -41 days at $12.5^{\circ} \mathrm{C}$ and 38 days at $20^{\circ} \mathrm{C}$ (Table 1). Treatment with $1-\mathrm{MCP}$ of the mature-green and full-red tomato fruit significantly extended storage potential of the fruit by 11 and 16 days respectively, compared to the untreated fruit. The best storage potential was found for full-red fruit treated with 1-MCP. These tomato fruit still had satisfactory market value (score of 5) after 48 days of storage at $12.5^{\circ} \mathrm{C}$. According to Adamicki \& Badelek (2003) 1-MCP is the most effective in delaying ripening of mature-green tomatoes, when they are stored at $12.5^{\circ} \mathrm{C}$, and is considered as a potential commercial treatment of field grown tomato destined for prolonged storage.

Table 1. Influence of 1-MCP treatment, and storage temperature on the market value in tomato fruit cv. Faustine $\mathrm{F}_{1}$, harvested in two stages of maturity

\begin{tabular}{|c|c|c|c|c|c|c|c|c|c|c|}
\hline \multirow{3}{*}{ Year } & \multirow{3}{*}{$\begin{array}{l}\text { Stage of } \\
\text { maturity } \\
\text { (A) }\end{array}$} & \multirow{3}{*}{$\begin{array}{l}\text { Temper- } \\
\text { ature } \\
\text { (C) }\end{array}$} & \multicolumn{4}{|c|}{ Market value after 4 weeks of storage } & \multicolumn{4}{|c|}{ Number of days to reach market value 5} \\
\hline & & & \multicolumn{3}{|c|}{ 1-MCP treatment $(\mathrm{B})$} & \multirow{2}{*}{$\bar{x}$} & \multicolumn{3}{|c|}{$1-\mathrm{MCP}$ treatment $(\mathrm{B})$} & \multirow{2}{*}{$\bar{x}$} \\
\hline & & & control & $1.0 \mu \mathrm{l} \cdot \mathrm{l}^{-1}$ & $2.0 \mu \mathrm{l} \cdot \mathrm{1}^{-1}$ & & control & $1.0 \mu 1 \cdot 1^{-1}$ & $2.0 \mu 1 \cdot 1^{-1}$ & \\
\hline \multirow{9}{*}{2008} & \multirow{3}{*}{$\begin{array}{l}\text { Mature- } \\
\text { green }\end{array}$} & $12.5^{\circ} \mathrm{C}$ & 7.4 & 8.9 & 8.7 & 8.3 & 35 & 46 & 43 & 41 \\
\hline & & $20{ }^{\circ} \mathrm{C}$ & 7.0 & 8.8 & 8.1 & 7.8 & 30 & 33 & 35 & 33 \\
\hline & & $\bar{x}$ & 7.2 & 8.8 & 8.4 & 8.1 & 32 & 39 & 39 & 37 \\
\hline & \multirow{3}{*}{ Full-red } & $12.5^{\circ} \mathrm{C}$ & 6.5 & 7.7 & 8.1 & 7.4 & 33 & 42 & 48 & 41 \\
\hline & & $20^{\circ} \mathrm{C}$ & 6.6 & 7.6 & 7.8 & 7.3 & 29 & 40 & 46 & 38 \\
\hline & & $\bar{x}$ & 6.5 & 7.6 & 7.9 & 7.3 & 31 & 41 & 47 & 40 \\
\hline & \multicolumn{2}{|c|}{$12.5^{\circ} \mathrm{C}$} & 6.9 & 8.3 & 8.4 & 7.9 & 34 & 44 & 45 & 41 \\
\hline & \multirow{2}{*}{\multicolumn{2}{|c|}{$20^{\circ} \mathrm{C}$}} & 6.8 & 8.2 & 7.9 & 7.6 & 29 & 36 & 40 & 35 \\
\hline & & $\bar{x}$ & 6.8 & 8.2 & 8.1 & 7.7 & 31 & 40 & 42 & 38 \\
\hline & \multicolumn{2}{|l|}{$\mathrm{LSD}_{0.05}$} & \multicolumn{4}{|c|}{$\begin{array}{l}\mathrm{A}-0.34, \mathrm{~B}-0.5 . \mathrm{C}-\mathrm{ns}, \mathrm{A} \times \mathrm{B}-\mathrm{ns} \\
\mathrm{A} \times \mathrm{C}-\mathrm{ns}, \mathrm{B} \times \mathrm{C}-\mathrm{ns}, \mathrm{A} \times \mathrm{B} \times \mathrm{C}-\mathrm{ns}\end{array}$} & \multicolumn{4}{|c|}{$\begin{array}{l}\mathrm{A}-\mathrm{ns}, \mathrm{B}-4.08, \mathrm{C}-2.74, \mathrm{~A} \times \mathrm{B}-5.76 \\
\mathrm{~A} \times \mathrm{C}-3.87, \mathrm{~B} \times \mathrm{C}-\mathrm{ns}, \mathrm{A} \times \mathrm{B} \times \mathrm{C}-\mathrm{ns}\end{array}$} \\
\hline \multirow{10}{*}{2009} & \multirow{3}{*}{$\begin{array}{l}\text { Mature- } \\
\text { green }\end{array}$} & $12.5^{\circ} \mathrm{C}$ & 7.7 & 8.1 & 8.1 & 7.9 & 35 & 39 & 41 & 38 \\
\hline & & $20^{\circ} \mathrm{C}$ & 6.2 & 7.2 & 7.9 & 7.1 & 28 & 30 & 31 & 30 \\
\hline & & $\bar{x}$ & 6.9 & 7.6 & 8.0 & 7.5 & 31 & 34 & 36 & 34 \\
\hline & \multirow{3}{*}{ Full-red } & $12.5^{\circ} \mathrm{C}$ & 6.2 & 8.0 & 8.1 & 7.4 & 28 & 42 & 41 & 37 \\
\hline & & $20^{\circ} \mathrm{C}$ & 6.9 & 7.7 & 8.3 & 7.6 & 31 & 40 & 40 & 37 \\
\hline & & $\bar{x}$ & 6.5 & 7.8 & 8.2 & 7.5 & 29 & 41 & 40 & 37 \\
\hline & \multicolumn{2}{|c|}{$12.5^{\circ} \mathrm{C}$} & 6.9 & 8.0 & 8.1 & 7.7 & 31 & 40 & 41 & 37 \\
\hline & \multicolumn{2}{|c|}{$20^{\circ} \mathrm{C}$} & 6.5 & 7.4 & 8.1 & 7.3 & 29 & 35 & 35 & 33 \\
\hline & \multicolumn{2}{|c|}{$\bar{x}$} & 6.7 & 7.7 & 8.1 & 7.5 & 30 & 37 & 38 & 35 \\
\hline & \multicolumn{2}{|l|}{$\mathrm{LSD}_{0.05}$} & \multicolumn{4}{|c|}{$\begin{array}{c}\mathrm{A}-\mathrm{ns}, \mathrm{B}-0.37, \mathrm{C}-0.25 \\
\mathrm{~A} \times \mathrm{B}-\mathrm{ns}, \mathrm{A} \times \mathrm{C}-0.35, \mathrm{~B} \times \mathrm{C}-\mathrm{ns} \\
\mathrm{A} \times \mathrm{B} \times \mathrm{C}-0.75\end{array}$} & \multicolumn{4}{|c|}{$\begin{array}{c}\mathrm{A}-1.37, \mathrm{~B}-2.04, \mathrm{C}-1.37 \\
\mathrm{~A} \times \mathrm{B}-2.88, \mathrm{~A} \times \mathrm{C}-1.94 \\
\mathrm{~B} \times \mathrm{C}-\mathrm{ns}, \mathrm{A} \times \mathrm{B} \times \mathrm{C}-\mathrm{ns}\end{array}$} \\
\hline
\end{tabular}




\section{CONCLUSIONS}

1. 1-MCP treatment of tomato fruit cv. Faustine $F_{1}$ significantly reduced respiration rate and ethylene production during storage.

2. Treatment of tomato fruit with 1-MCP reduced natural weight loss during the storage period compared to the untreated fruit.

3. Storage potential and market value of tomato fruit depended on the treatment with 1-MCP, stage of maturity and storage temperature.

4. The lowest market value was observed for tomato fruit harvested as a mature-green, untreated with 1-MCP and stored at $20^{\circ} \mathrm{C}$.

\section{REFERENCES}

Adamicki F. 1991. Wpływ temperatury i kontrolowanej atmosfery na przechowywanie, dojrzewanie i jakość owoców pomidorów. Praca habilitacyjna, Instytut Warzywnictwa w Skierniewicach. (in Polish)

Adamicki F., Badełek E. 2006. The studies on new technologies for storage prolongation and maintaining the high quality of vegetables. Vegetable Crops Research Bulletin 65: 63-72.

Blankenship S.M., Dole J.M. 2003. 1-Methylcyclopropene: a review. Postharvest Biology and Technology 28: 1-25. DOI: 10.1016/S0925-5214(02)00246-6.

Castro L.R., Vigneault C., Charles M.T., Cortez L.A.B. 2005. Effect of cooling delay and cold-chain breakage on 'Santa Clara' tomato. Journal Food Agriculture and Environment 3: 49-54.

Colelli G., Sánchez M.T., Torralbo F.J., 2003. Effects of treatment with 1-methylcyclopropene (1-MCP) on tomato. Alimentaria 342: 930-934.

Ergun M., Sargent S.A., Huber D. 2006. Postharvest quality of grape tomatoes treated with 1-methylcyclopropene at advanced ripeness stages. HortScience 41(1): 183-187.

Gajewski M. 2001. Przechowalnictwo warzyw. Wydawnictwo SGGW. (in Polish)

Getinet H., Seyoum T., Woldetsadik K. 2008. The effect of cultivar, maturity stage and storage environment on quality of tomatoes. Journal of Food Engineering 87: 467-478. DOI: 10.5897/AJB11.652.

Guillén F., Castillo S., Zapata P.J, Martínez-Romero D., Serrano M., Valero D. 2007. Efficacy of 1-MCP treatment in tomato fruit. Duration and concentration of 1MCP treatment to gain an effective delay of postharvest ripening. Postharvest Biology and Technology 43: 23-27. DOI: 10.1016/j.postharvbio.2006.07.004.
Hoeberichts F.A., van der Plas L.H.W., Woltering E.J. 2002. Ethylene perception is required for the expression of tomato ripening-related genes and associated physiological changes even at advanced stages of ripening. Postharvest Biology and Technology 26: 125-133. DOI: 10.1016/S0925-5214(02)00012-1.

Krammes J.G., Megguer C.A., Argenta L.C., Amarante C.V.T., Grossi D. 2003. Use of 1-methycyclopropene to delay fruit ripening of tomato. Horticulture of Brasilia 21: 611-614. (in Portuguese with English abstract)

Leliévre J.M., Latché A., Jones B., Bouzayen M., Pech J.C. 1997. Ethylene and fruit ripening. Physiology Plantarum 101: 727-739.

Mir N.A, Canoles M., Beaudry R., Baldwin E., Pal Mehla C. 2004. Inhibiting tomato ripening with 1methylcyclopropene. Journal of the American Society for the Horticultural Science 129: 112-120.

Mostofi Y., Toivonen P.M.A. 2006. Effects of storage conditions and 1-Methylcyclopropene on some qualitative characteristics of tomato fruits. International Journal Agriculture and Biology 8: 93-96.

Mostofi Y., Toivonen P.M.A., Lessani H., Babalar M., Lu C.W. 2003. Effects of 1-methylcyclopopene on ripening of greenhouse tomatoes at three storage temperatures. Postharvest Biology and Technology 27: 285-292. DOI: 10.1016/S0925-5214(02)00113-8.

Opiyo A.M., Ying T.J. 2005. The effects of 1-methylcyclopropene treatment on the shelf life and quality of cherry tomato (Lycopersicon esculentum var. cerasiforme) fruit. International Journal Food Science Technology 40: 665-673. DOI: 10.1111/j.13652621.2005.00977.x.

Pangaribuan D.H., Irving D.E. 2010. The effect of 1-MCP in maintaining the quality of tomato slices. Jurnal Teknologi dan Industri Pangan 21(1): 80-85.

Sun X., Wang Z., Li Z., Wang W., Zhang Z. 2003. Effects of 1-MCP on postharvest physiology of tomato. Agricultural Sciences in China 2(6): 663-669.

Suszyna J. 2006. Influence of extreme moisture conditions on yielding of tomato in field cultivation. Folia Horticulturae Suppl. 2: 181-185.

Telefera A., Seyoum T., Woldetsadik K. 2007. Effect of disinfection, packaging and storage environment on the shelf life of mango. Biosystems Engineering 96(2): 1537-1550. DOI: 10.1016/j.biosystemseng.2006.10.006.

Wills R.B.H., Ku V.V.V. 2002. Use of 1-MCP to extend the time to ripen of green tomatoes and postharvest life of ripe tomatoes. Postharvest Biology and Technology 26: $85-90$. DOI: $10.1016 /$ S09255214(01)00201-0.

Žnidarčič D., Požrl T. 2006. Comparative study of quality changes in tomato cv. 'Malike' (Lycopersicon esculentum Mill.) whilst stored at different temperatures. Acta Agriculture Slovenica 87-2: 235-243. 